\title{
FACTORS OF PARENTAL INVOLVEMENT IN RELATION TO CHILDREN'S BEHAVIORAL SYMPTOMS
}

\author{
Authors: \\ Anita Kathyné Mogyoróssy \\ Debreceni Református Hittudományi \\ Egyetem \\ Erika Beáta Nagy \\ University of Debrecen \\ E-mail address of the first author: \\ kathyne@gmail.com
}

Lectors:

\author{
Ildikó Pinczésné Palásthy \\ Debreceni Református Hittudományi \\ Egyetem \\ George Seel \\ University of Debrecen \\ Ferenc Mező \\ Eszterházy Károly University \\ Edina Szabó \\ University of Debrecen
}

Kathyné Mogyoróssy, Anita and Nagy, Erika Beáta (2017): Factors of parental involvement in relation to children's behavioral symptoms. Különleges Bánásmód, III. évf. 2017/1. szám, 7-25. DOI 10.18458/KB.2017.1.7

\begin{abstract}
In our study the features of contact between parents and teachers and the particular patterns they take were examined in connection with children's behavioural symptoms. With cluster analysis, seven clearly analysable patterns of contact were identified, the two most frequent of which (unifacial and formal) do not favour problem solving, nor provide parental satisfaction.

Two patterns (flexible and adaptive) proved to be the most satisfying and the most effective. Children's symptoms (social problems, anxiety, somatization, attention deficit, deviant behaviour, agressivity) are significantly related to the quality of parent-teacher contact. In the case of the less favourable and less effective contact forms, parents report more behavioural symptoms, while in the case of the flexible, adaptive, emotionally satisfying and effective problem solving contact forms, there are fewer symptoms. These results draw attention to important tasks on many levels: to work out operable patterns of parent-teacher contact, to better understand the role and tasks of teacher training, and the need to involve experts to assist in developing parent-teacher contact, which is also indispensable in terms of helping and developing children and their mental health.
\end{abstract}

Keywords: Parental involvement, Parent-pedagogue contact, Children's behavioural symptoms, Teacher training

Disciplines: Psychology, Pedagogy

\footnotetext{
${ }^{1}$ The editorial board does not take any responsibilty for the English of the papers. Indeed, we made some slight changes but wanted to keep the style of the authors.
} 


\section{Absztrakt}

Tanulmányunkban a szülők és a pedagógusok kapcsolattatásának jellegzetességeit, mintázatait tártuk fel a gyermekek viselkedéses tüneteivel összefüggésben. Klaszteranalízis segítségével hét jól értelmezhető kapcsolattartási mintázatot sikerült azonosítani, melyek közül a leggyakoribb kettő (egysíkú és formális) nem kedvez a problémamegoldásnak és a szülöi elégedettségnek. Két mintázat (rugalmas és adaptív) bizonyult a legkielégítőbbnek és leghatékonyabbnak. A gyermekek tünetei (társkapcsolati problémák, szorongás, szomatizáció, figyelmi problémák, deviáns viselkedés, agresszivitás) és a szülő-pedagógus kapcsolattartás minősége szignifikánsan összefügg. A legkevésbé kedvező és hatékony kapcsolattartási formák esetében több gyermeki tünetröl számolnak be a szülők, míg a rugalmas, adaptív, érzelmileg kielégítő és a problémamegoldásban sikeres kapcsolati formák esetében kevesebb tünet jelentkezik. Ezek az eredmények fontos feladatokra hívják fel a figyelmet több síkon is: a szülő-pedagógus kapcsolattartás müködőképes formáinak kidolgozására, a pedagógusképzés szerepére és feladataira, illetve a segítő szakemberek bevonásának szükségességére a szülöpedagógus kapcsolat fejlesztése céljából, ami a gyermekek segítése, fejlesztése, mentálhigiénéje szempontjából is elengedhetetlen.

Kulcsszavak: szülői bevonódás, szülö-pedagógus kapcsolattartás, gyermekviselkedési tünetek, pedagógusképzés

Diszciplína: Pszichológia, pedagógia

Parent-teacher cooperation is a necessary condition for the effective upbringing and education of children. As provided by the National Public Education Law (2011. CXC.) of Hungary and other documents, parents have the right to be involved in school life, something which is both their obligation and responsibility.

Social processes are manifest in the education system: the system recognises social, economic, and political changes and reacts to these phenomena. School can also be considered a reduced society. In the last few years global phenomena (multiculturalism, Americanization, the consumer society) have been recognisable features of school life (Torgyik, 2009).

There are great differences in regard to what parents consider a teacher's tasks. Some parents emphasize upbringing-related tasks and the role of the teacher's personality as a guide (Hunyadi, 2002), while others believe teachers' competence only extends to educational tasks (Lénárd, 2003).

When an educational problem occurs, both amateurs and experts have suggestions about how to solve it; however, these adult roles are different in many ways. The parental role carries with it a certain degree of prejudice, a high level of emotional intensity, and strong bonding; its extent is limitless, and its main dimension is care. The teacher's role, on the other hand, is objective, keeps optimal emotional distance, and is not responsible for all areas of life, but only education (Katona and Szitó, 2005).

Successful cooperation is more difficult because of the social and economic status of the family, the qualifications of the parents and their values. Consequently, their educational attitudes, conflict management strategies and communication styles are different; moreover, it often happens that these also differ from the school's own expectations. (When teachers evaluate children their values and personalities also filter into the cooperation relationship) (Szabó, 2006). 


\section{Typical forms of parent-teacher contact in Hungary}

Füle examined the most typical contact forms in 1983 and 1991 in Budapest, and proposed solutions to make them better, solutions which are still valid today (Füle, 2002).

Éva Szabó offered suggested solutions in her study of 2003. She pointed out that circumstances are also important: on which occasions, how often and in what atmosphere do teachers and parents meet each other. Hegedüs and Podráczky (2011) asked teachers and parents about forms of contact in focus group discussions.

According to Füle's results, parents often have different needs from what is discussed at parents' meetings. It would be preferable to carry out a prior needs assessment, and after this for parents and teachers to determine topics together (Füle, 2002).

Parents' meetings are usually organized in the classroom. Its layout creates a superiorsubordinate relationship and parents tend to re-live their own school memories, which reproduce old reactions, too (for example anxiety, defiance, subservience, passivity). Other layouts (chairs placed around the room, or in a U-shape) could be an alternative which would suggest equal contact and create the feeling that everybody's opinion is important.

Information is often impersonal and unilateral; there is no discussion, only statements. One solution would be to communicate information where no discussion is needed in other ways (letter, reminder, e-mail, up-to-date website, chat forums). This would make more time which could be used to organize discussions which are closer to topics that parents wish to talk about. These discussions could be informal conversations, or educational lectures (with guest lecturers) which finish with a discussion. Teachers could also present the methods they use, or review a book (Szabó, 2006). Regular participation in parents' meetings is harder, because the appointments are in working hours (Hegedüs and Podráczky, 2012).

In the case of consulting hours, it is necessary to emphasize the environment: cosy, separated rooms make for calm conversation. The topics for discussion at consulting hours are generally school requirements, methods, textbooks, further education opportunities, free time at school, other opportunities, the child's out of school activities, the school calendar and any problems arising. It is important to make a clear agreement in terms of what the teacher, the parent and the child need to do to solve the problem (Füle, 2002). The consulting hour's greatest enemy is the lack of time.

According to Júlia Szekszárdi's (2000) results, teacher-parent contact is mainly limited to dealing with problems.

In focus group discussions another, totally different, problem occurs: usually the parents who appear in consulting hours are caring parents who want to be informed about their child's positive progress and need their competence as parents to be confirmed (Hegedüs and Podráczky, 2012).

Éva Szabó divides the tasks carried out in consulting hours into pre-, during and postconsultation tasks. Prearranged appointments could be a part of the arrangement, so that any rush could be avoided. Making prior appointments and fixing their duration make contact more calculable, concentrated and efficient. It is useful to keep some perspective and use well-tried methods. It is worth making positive comments about the child and then inviting the parents to speak, to discover their view-point. Then the teacher can give his/her opinion about the child and continue with any proposed solutions and strategies. Finally, it is practical to close the conversation with encouragement and make a new appointment with the parents, when they can evaluate the results (Szabó, 2006).

In Füle's opinion open days are, above all, a way of satisfying curious parents: they can see what their child's everyday school life is like, and observe their relationships with classmates and teachers (Füle, 2002).

It is very important that parents observe real school life, and open days and chances for classroom observation should be more regular. In this way parents can get a real perspective 
on school work, try to understand the teacher's position and avoid the feeling that they are only seeing the 'shop window' (Szabó, 2006).

Márta Winkler (2003) also emphasizes that parents should be involved in school life through regular classroom observation with the aim of getting to know teachers and their educational principles, as well as the community the child is studying in. She stresses the importance of common experiences, and urges out of school contact between children and family. The educational effectiveness of a teacher is multiplied in a frank atmosphere when the child's real interests are represented by parents and teachers in mutual understanding.

In 1991 Füle (2002) reported regular home visits, but nowadays these are not obligatory in public education, and parents cannot be forced to let anyone (even teachers) into their home. In focus group examinations most teachers mentioned overwork and the lack of time (Hegedüs and Podráczky, 2012). In my experience teachers mainly propose family visits when they think this is the only possibility to meet the parents. The type of settlement may also influence whether or not parents take advantage of this opportunity. In smaller settlements, where people know each other, it could be more typical.

There are other possibilities beside personal contact. A message booklet can keep parents up-to-date with their child's performance, attitude and other important information, although it does not inform them about their child's behaviour and general well-being, unless the teacher feels it indicates a problem.

Different forms of electronic communication (telephone, e-mail, websites) are quite typical in families with higher social and economic status. Beside the discriminating effect of significant social differences, teachers mentioned that parents can misuse the opportunities offered by electronic communication.

According to focus group surveys, the other, alternative forms of contact (freetime hobbies, common events) are less preferred, because of the lack of time (Hegedüs and Podráczky, 2012).

Judit Lannert and Júlia Szekszárdi carried out an online investigation in 2013 into contact between parents and teachers. According to their results, more than half of parents do not use the majority of communication possibilities available. Contact between parents and teachers is not intensive; they meet more or less quarterly or termly. The most typical forms of communication are the parents' meeting and the message booklet. Although the consulting hour is not the most frequent, both parents and teachers think it is the most effective, mainly because of the opportunity it offers for personal contact. As we can see, the older the child, the less active the contact between parent and teacher. By the time the child goes to high school, this contact has become totally impersonal; in line with this, and, as a consequence of it, in the judgement of the parents there is a steady deterioration in the quality of the contact.

According to the authors this situation can be explained: most parents (and the majority of teachers) are not aware of the communication possibilities that exist. This field is not dealt with in teacher training - there is no direct training to be a form tutor. So most teachers use their own, characteristically traditional, deficient experiences, and so bad habits are continued from generation to generation.

Parents, however, want to receive support in educational topics, a point which is demonstrated by the existence of popular online forums (Lannert and Szekszárdi, 2015).

\section{RESEARCH}

The aim and hypotheses of this study

Aim: In our study the features of contact between parents and teachers and the special patterns of this contact were examined in relation to children's behavioural symptoms. 
Hypothesis 1: We supposed that frequent and flexible contact possibilities were considered more positive by parents if they help successful cooperation and solve any problems that have occurred.

Hypothesis 2: We supposed that when forms of parent-teacher contact are more appropriate, children have fewer behavioural problems.

Hypothesis 3: We supposed that the children of parents who have more positive contact with teachers have fewer behavioural problems.

\section{Participants in the study}

1464 subjects took part in our study, all of whom were parents of 6-12 year old children. $85 \%$ of the participants were women (mother), 15\% men (father). This difference can be explained by the fact that child rearing and keeping contact with the school are traditionally tasks carried out by mothers. This research was conducted from 2015 to 2016.

\section{Measures used:}

1. The CBCL (Child Behaviour Checklist) (Gádoros, 2007): the version for parents of 7-14 year old children. The Child Behaviour Checklist (CBCL) questionnaire was edited by Th. Achenbach et al. in the 1980s on the basis of symptom lists created to diagnose and measure the behavioural and emotional problems of children and adolescents. The original questionnaire contains 114 items, and 8 problem scales; the abridged version which was tested by Hungarian children, was called the Child Behaviour Checklist (Gyermekviselkedési Kérdöív), and is linked with the name of Júlia Gádoros. The abridged Hungarian version has three subvariants, depending on who the subject is. The teacher's version contains 47 questions, the parent's version contains 46 questions, and normative values refer to 4-14 year old children. The self-assessment version contains 44 questions and normative values refer to 10-14 year old children. All the three versions have 6 scales, each of which have a further 3 scales.

a. Problems with social connections scale: this scale indicates children's problems with their classmates and with their parents.

b. Anxiety, depression scale: summarizes emotional symptoms relating to anxiety and mood disorders.

c. Somatization scale: summarizes physical symptoms which have no known medical cause.

d. Attention deficit scale: mainly refers to problems with attention deficit and hyperactivity.

e. Deviant behaviour scale: summarizes indications relating to violations of required behavioural norms.

f. Agressivity scale: refers to a child's impetuosity, agressivity and aptitude for destruction

g. Internalization: a summarized scale created from the problems of social communication scale and the anxiety/depression scale. These symptoms occur in a child's emotional life and they present difficulties mainly for the child, who suffers from these symptoms, and not for the surrounding environment.

Externalization: a summarized scale created from the deviant behaviour scale and the agressivity scale. It includes behaviours which disturb the surrounding environment.

The total value of problems: the total value of the 6 scales. 
High scores for internalization may indicate an excess of control, while high scores for externalization may indicate undercontrolled behaviour (Bíró, 2010).

2. The types of contact between parents and teachers and the level of satisfaction with the contact were examined by metaphor analysis and with a short questionnaire. The meaning of the word metaphor is 'transmission'; when we link two concepts together by the similarity of their content. In the course of creating metaphors, the deeper, unconscious elements and experiences of our personality may emerge (Vámos, 2001). We used the metaphor analysis method by creating independent metaphors. Subjects were asked to describe the relationship between parents and teachers, by continuing the following sentence: The relationship between parents and teachers is like..., and to explain their answers.

The answers were analysed by content analysis. According to the metaphors produced, we created two derived variables during the data analysis and category creation:

- The emotional quality of the relationship between parents and teachers (negative or ambivalent, neutral, positive).

- The equality of the relationship between parents and teachers (equal, subordinatesuperior).

Other variables were based on the questions in the questionnaire:

- 'How do you consider your relationship with your child's teacher/form tutor?' (not good, acceptable, good, excellent)

- 'If any problem occurs how can you cooperate?' (insufficiently, quite well, very well)

- 'How often do you have contact?' (once a half-year or more rarely, quarterly, once a month, up to several times a week)

- 'Do you think the frequency of contact is sufficient?' (not sufficient, sufficient, totally sufficient)

- 'Do you think this form of contact is adequate?' (not adequate, adequate, totally adequate)

- How do you maintain contact with your child's teacher/form tutor? (parents' meetings, consulting hours, by appointment, by phone, family visit, other)

In the 'other' category there were several answers relating to the nature of the contact: informal, unintended, random (anytime, anywhere, whenever, in the morning before teaching, in the afternoon after teaching, on the street); all of these were grouped together and interpreted as 'informal'.

The contact by e-mail and by telephone categories were grouped together and were interpreted as 'telecommunication'.

Neither message booklet and nor electronic mark-book (these are special Hungarian methods used to communicate with parents) were represented in the sample to a significant degree (under 1\%).

Data were analysed with the help of SPSS version 13.0 software. Cluster analysis, Pearson's chi-squared test, the Kruskal-Wallis test, the Jonckheere-Terpstra test and the Mann-Whitney test were all used.

\section{RESULTS}

Answers relating to the contact between parents and pedagogues were distributed as follows: 
Emotional quality and the equality of the relationship between parents and teachers

When examining data by metaphor analysis, $66.2 \%$ of the sample created metaphors. $10.1 \%$ of these subjects considered the emotional quality of the relationship between parents and teachers to be negative or ambivalent, $50.2 \%$ considered it to be neutral and $39.7 \%$ positive.

As regards equality, $89.3 \%$ of the respondents considered the relationship between parents and teachers to be equal, and $9.6 \%$ subservient, while in $5.1 \%$ of cases the metaphor did not refer to the relationship. These latter variables were not taken into consideration when making comparisons with other variables.

\section{How do parents view the relationship?}

$42.6 \%$ of the subjects considered the relationship to be excellent, $40.4 \%$ good, $14.3 \%$ acceptable, while $1.9 \%$ of the respondents thought it was not good. (These results correspond with Füle's poll results (1983) in which $84 \%$ of parents were pleased with the quality of education to a certain extent). This is a very positive result, when compared with the emotional quality of the relationship (which resulted in less positive results), so we can see that in the case of metaphor analysis the subjects had less intention of creating the kind of answers which were expected. When the process of responding is not limited to exclusively conscious factors we can acquire a much more subtle picture.

'Cooperation when a problem occurs' was judged quite positively by respondents (but not excessively so): $51.9 \%$ of them considered the level of cooperation to be very good, $39.9 \%$ quite good, and $7.9 \%$ insufficient.

\section{Satisfaction with the frequency of meetings}

More than half of the subjects contact their child's teacher/form tutor once a month, or more rarely (there was no real difference in frequency between primary school and middle school). $55.1 \%$ respondents reported this frequency as totally sufficient, according to $38.7 \%$ it was quite sufficient, while $5.5 \%$ considered it insufficient.

The Pearson's chi-squared test revealed that these two outcome variables have a significant relationship. The more frequent the contact between parents and teachers, the more satisfied the parents are.

Further correlations are observable between certain variables.

The Kruskal-Wallis test revealed a significant relationship between all other dichotomous variables $(p<0.01)$, except for equality. The Jonckheere-Terpstra test (which measures monotony) also revealed significant results (at least $\mathrm{p}<0.05$ ).

Those parents who had a positive view of the nature and the emotional quality of the relationship between parents and teachers tend to have more frequent contact and are more satisfied with the frequency and the type of contact, and they feel cooperation is more successful when a problem occurs (see Figure 1) than those parents who considered the relationship sufficient or quite good, or who had a no more than neutral view of the emotional quality of the relationship. 
Figure 1-Relationship between cooperation when a problem occurs and quality of contact

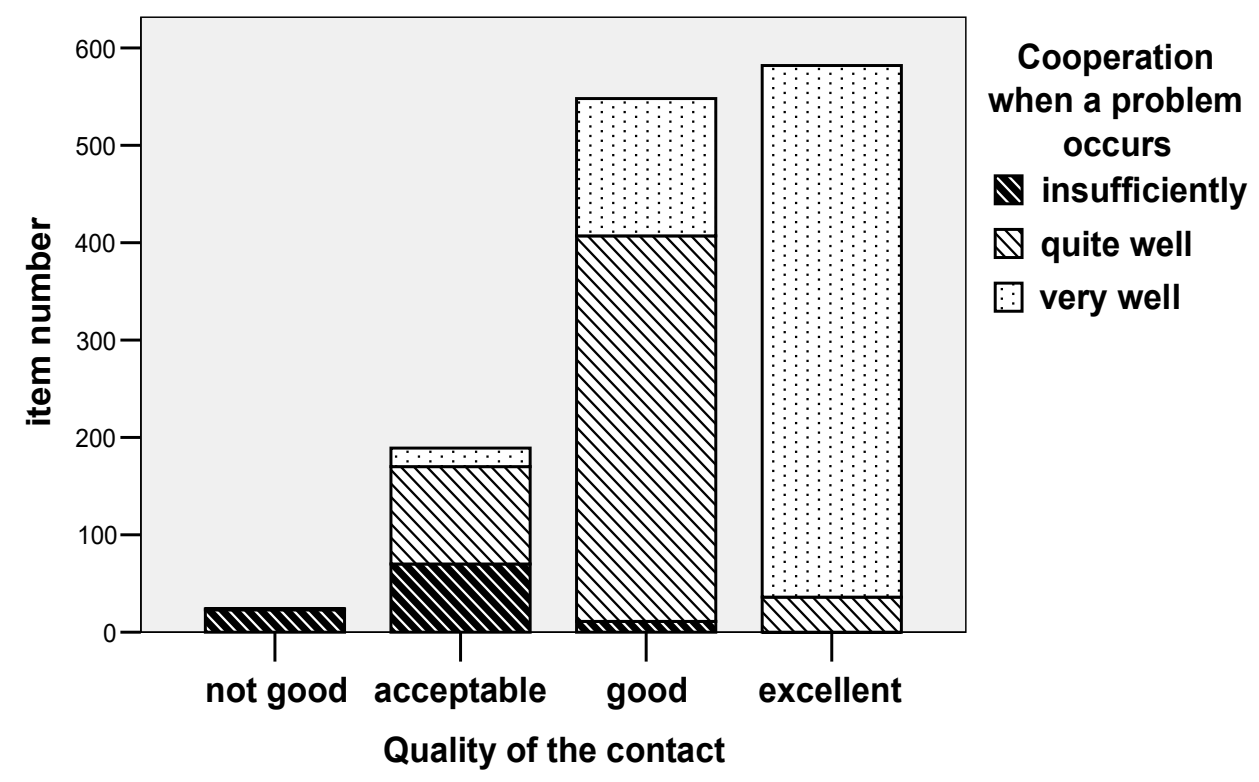

As regards the question of frequency, there is a positive correlation between more frequent contact and the other variables. Those parents who meet more frequently with their child's teacher are more satisfied with the frequency and the type of the contact, as well as with the relationship between parents and teachers and with problem solving (see Figure 2). Satisfaction with frequency revealed the same clear correlations.

\section{Figure 2 - Relations between cooperation when a problem occurs and frequency of contact}

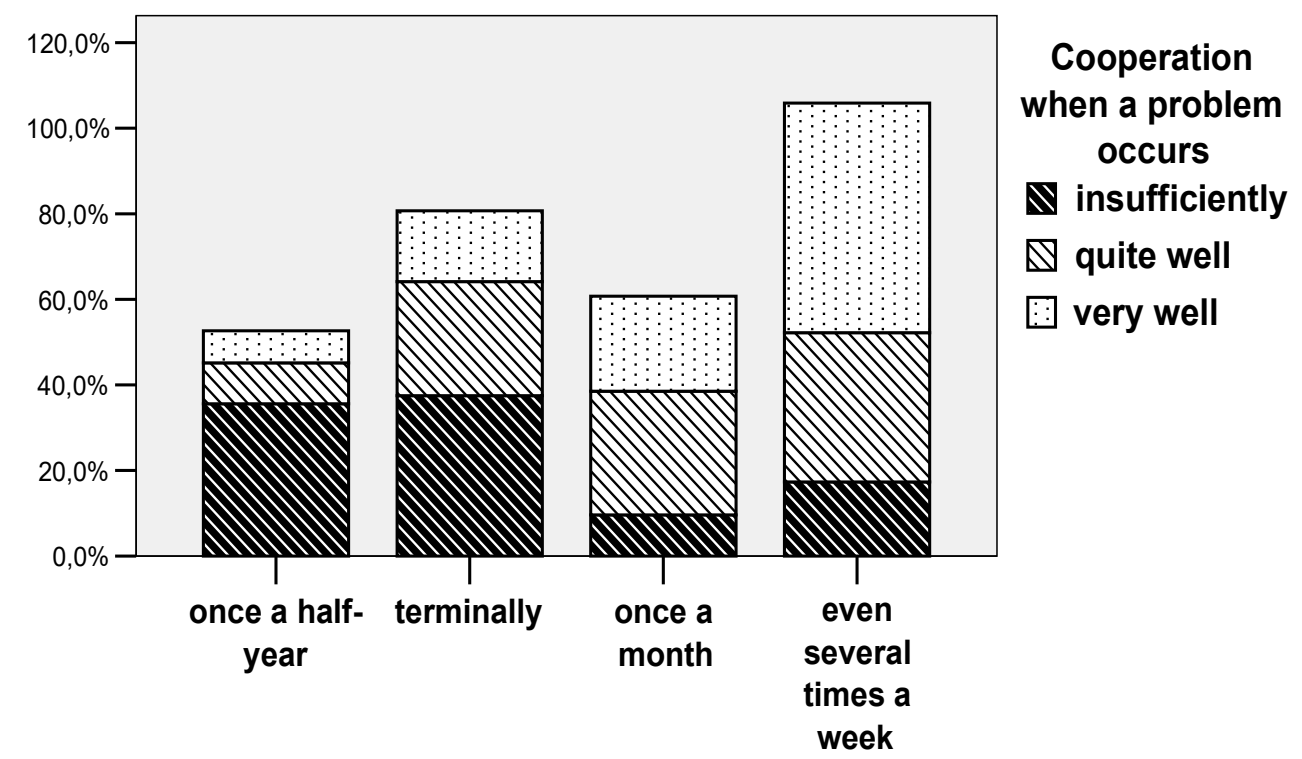

Frequency of the contact

These results draw attention to the fact that parents and teachers need to be motivated to meet frequently.

There is a strong significant correlation between cooperation when a problem occurs (as we have already observed) and the other variables: the more frequent the contact, and the more satisfied the parents are with it, and the more positive they consider the relationship, the more 
they can cooperate if any problem occurs. When they are less satisfied, the relationship is more negative and less frequent, which has a negative effect on cooperation, too.

The question of equality divides the sample of parents who answered the metaphor question into two subgroups: those who feel the relationship is an equal one, and those who feel it is a relationship between subordinate and superior. The Mann-Whitney test revealed a significant difference between the two subgroups as regards emotional quality: an equal relationship means a more positive emotional relationship at the same time.

Examining the typical forms of relationships we found that parents tend to use the conventional and organized forms of contact offered by the school: parents' meetings and consulting hours (which rarely conform to parents' needs). These are complemented with more flexible types of contacts, such as telecommunication, and informal meetings. As we can see, the home visit has fallen out of favour, due to the fact that, on the one hand that is not obligatory for teachers, while on the other hand parents are not obliged to let anyone into their home if they do not want to (see Table 1).

Table 1 - percentage breakdown of forms of contact

\begin{tabular}{|l|l|}
\hline Forms of contact & Percentage of parents \\
\hline parents' meetings & $87.2 \%$ \\
\hline consulting hours & $35.4 \%$ \\
\hline telecommunication & $31.4 \%$ \\
\hline informal meetings & $14.4 \%$ \\
\hline previously agreed meetings & $10.9 \%$ \\
\hline home visits & $2.0 \%$ \\
\hline
\end{tabular}

To the question 'Do you think this form of contact is adequate?' $61.8 \%$ of the parents answere that it is totally adequate, $32.6 \%$ found it adequate and only $4.7 \%$ said that it is not adequate. In in most primary schools in the Hungarian public education system, there is a parents' meeting 3-4 times a year.

Figure 3 - The patterns of contact

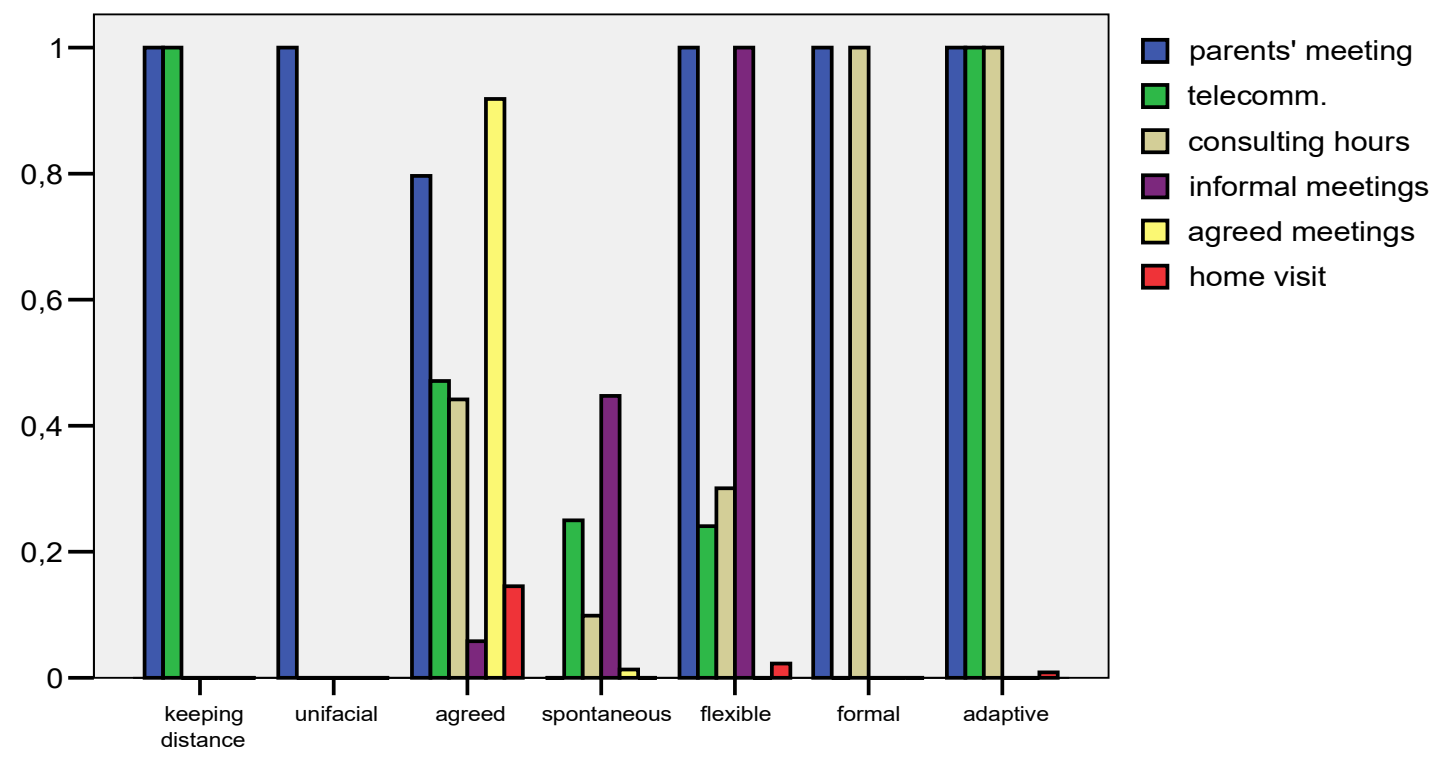


Considering the children's age (6-12 years) and the requirements of effective problem solving, in many cases the contact is infrequent and characterized by conventional, rigid forms. We think that the reason for this is firstly habit (parents' own school socialization), and secondly the lack of other alternatives. According to demographic parameters, the younger age-group prefer flexible types of contact, which have been introduced as a result of the increasing openness of schools after the political changes of 1989-90.

These data were examined with cluster analysis; seven clusters were identified, which indicate clearly analysable patterns of contact (see Figure 3).

We tried to give these clusters clear, precise names, which express the essentials of certain patterns of contact (see Table 2). We started with the characteristics of certain types of relationships: the parents' meeting is not so personal, because the subject is the class not the child, but it may create the opportunity for parents to get to know each other and declare their intention of cooperating with the school. The consulting hour is personal, but the disadvantage is that the parent or teacher cannot react immediately when they want to negotiate something. An informal meeting is personal and flexible, but there is less time to talk because there is no fixed appointment. Telecommunication is fast; if any problem occurs, we can talk immediately, but there is no personal presence, non-verbal communication is deemphasized and the time is limited. So we can see that, on its own, each type of contact is incomplete.

The patterns of contacts and their labels and their percentages are presented in the chart below.

Table 2 - Percentage breakdown of the patterns of contact

\begin{tabular}{|l|l|r|r|}
\hline The patterns of contact & Name & Respondent $(s)(n)$ \\
\hline 1: parents' meetings + telecommunication & $\begin{array}{l}\text { Keeping distance } \\
\text { (see Figure 4) }\end{array}$ & 13.2 & 193 \\
\hline 2: only parents' meetings & $\begin{array}{l}\text { Unifacial } \\
\text { (see Figure 5) }\end{array}$ & 28.8 & 172 \\
\hline $\begin{array}{l}\text { 3: pre-arranged meetings + parents' } \\
\text { meetings + telecommunication + } \\
\text { consulting hours + home visit }\end{array}$ & $\begin{array}{l}\text { Agreed } \\
\text { (see Figure 6) }\end{array}$ & 11.8 & 152 \\
\hline 4: informal meetings & $\begin{array}{l}\text { Spontaneous } \\
\text { (see Figure 7) }\end{array}$ & 10.4 & 275 \\
\hline 5: parents' meetings + informal meetings & $\begin{array}{l}\text { Flexible } \\
\text { (see Figure 8) }\end{array}$ & 9.1 & 116 \\
\hline 6: consulting hours + parents' meetings & $\begin{array}{l}\text { Formal } \\
\text { (see Figure 9) }\end{array}$ & 18.8 & $\begin{array}{l}\text { Adaptive } \\
\text { (see Figure 10) }\end{array}$ \\
\hline $\begin{array}{l}\text { 7: telecommunication + consulting hours } \\
+ \text { parents' meetings }\end{array}$ & 7.9 & \\
\hline
\end{tabular}

Below, we review certain clusters and their features. 
Figure 4 - The patterns of contact: Keeping distance

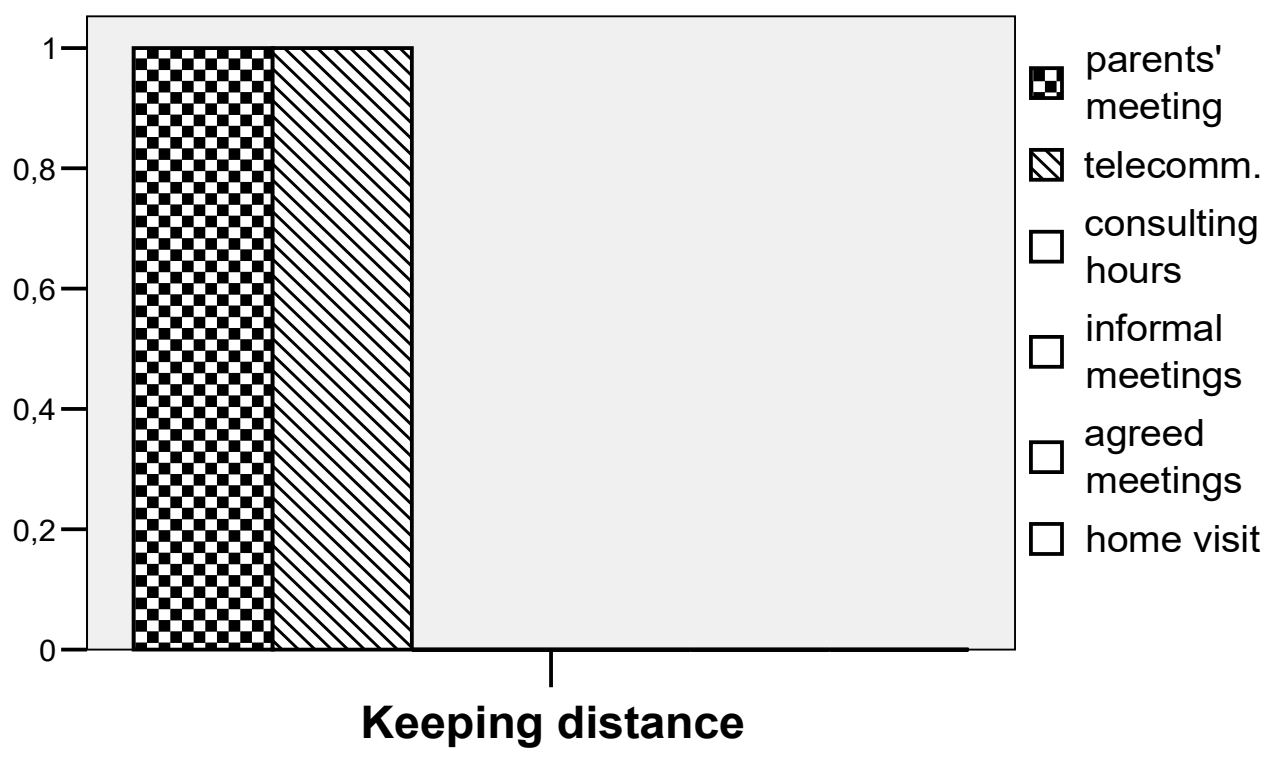

In Cluster 1, named 'Keeping distance', are parents who usually go to parents' meetings and keep in touch with the teacher by telecommunication methods. In this cluster there is no personal and close relationship, since there is no possibility to talk in private and spend enough time to talk about the child.

Figure 5 - The patterns of contact: Unifacial



In Cluster 2, called 'Unifacial', are parents who only go to parents' meetings. They do not make the most of the opportunities presented to them, and their contact with the teacher is minimal. There is no personal interview, nor flexibility and adaptivity in the relationship. 


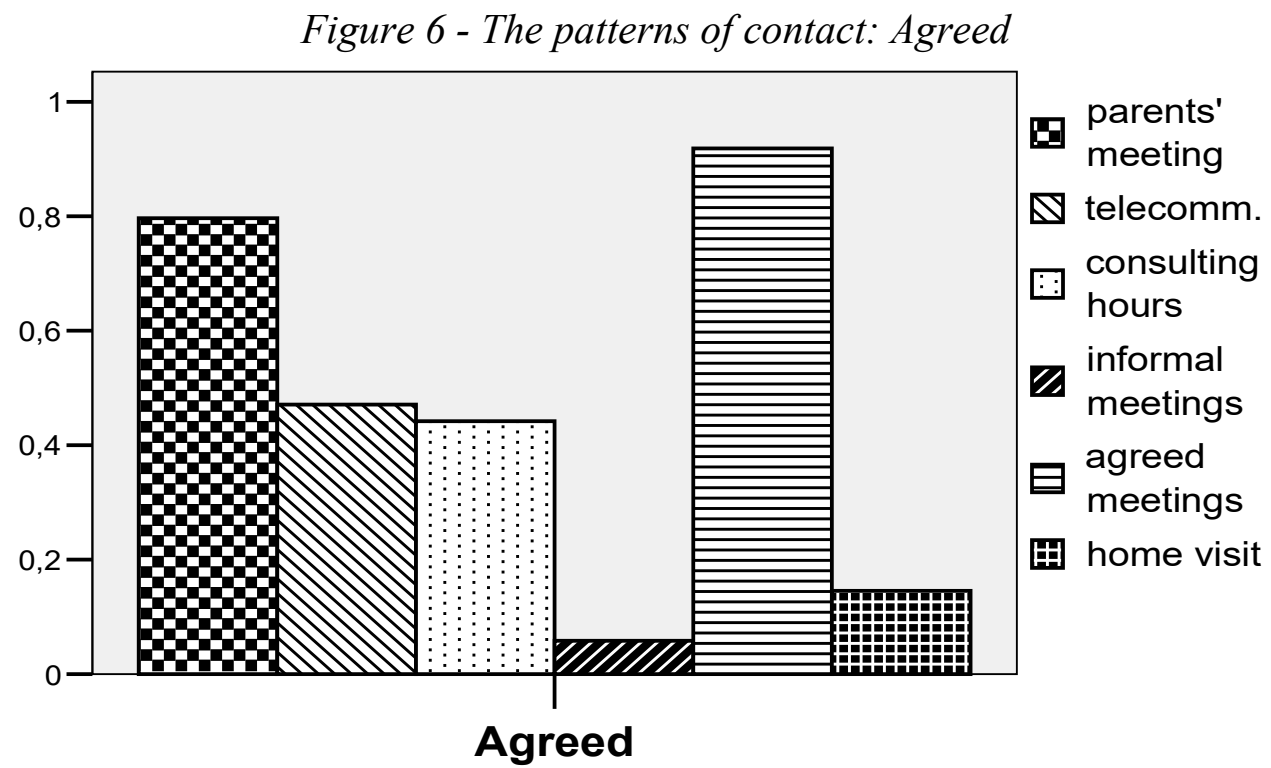

Cluster 3, named 'Agreed' because fixed appointments only occur in this cluster, represents the typical form of contact for $90 \%$ of parents. Family visits also only occur here, but do not exceed $20 \%$. $80 \%$ of parents attend parents' meetings in this cluster, and there are parents who take the opportunity and use telecommunication methods and consulting hours. We can probably include in this cluster parents who are invited in by the teacher. The teacher makes the appointment or visits the family. This assumption is reinforced by the fact that these parents reported significantly more symptoms related to their children, so here we can find parents of 'problematic children'. Of course, the parents may also initiate the appointment.

Figure 7 - The patterns of contact: Spontaneous

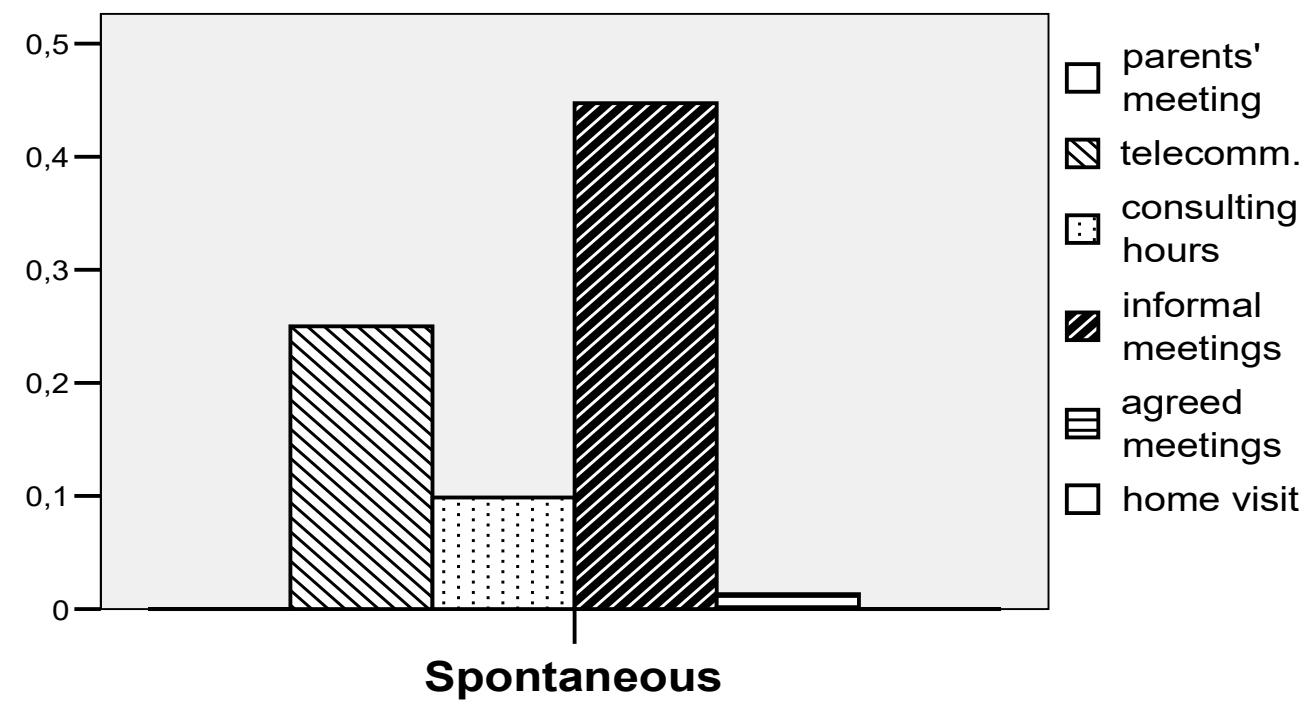

Analysing Cluster 4 ('Spontaneous'), we can see that parents do not go to parents' meetings at all. Other possibilities were less used by these parents than by others. Informal meetings and telecommunication methods are the most typical forms used to keep in touch, although they do not reach $50 \%$ on the scale. Examining this cluster in more detail, we found that it is 
less homogeneous than the others. In this cluster there are 152 parents, $40 \%$ of whom do not have contact by informal meeting, nor by telecommunication method, so essentially not at all. $35 \%$ of them keep contact informally, $20 \%$ by phone or by e-mail, and $5 \%$ use both forms.

Figure 8 - The patterns of contact: Flexible

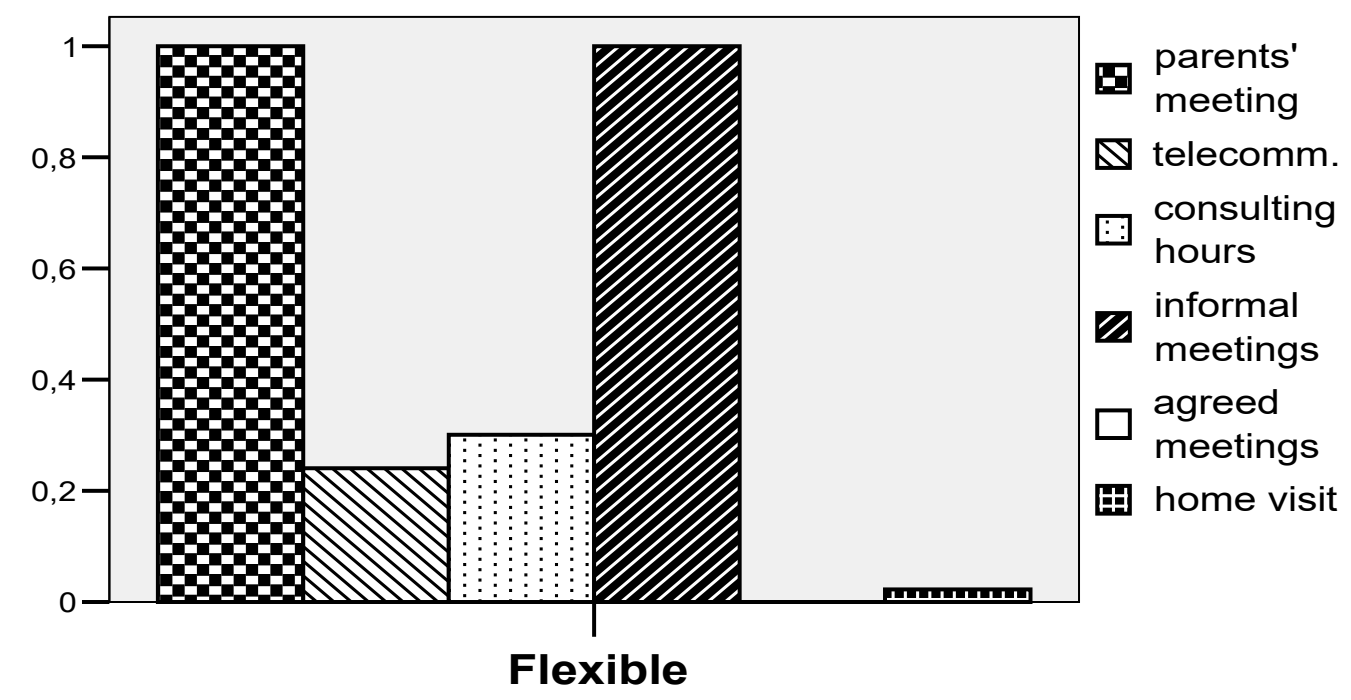

Cluster 5 is labelled 'Flexible', because besides parents' meetings, a full range of informal meetings occur, so these parents know they can visit the teacher at any time. They are involved in school life because of their collective interest in the parents' meetings, and are also linked to the teacher through the option of informal meetings.

Figure 9 - The patterns of contact: Formal

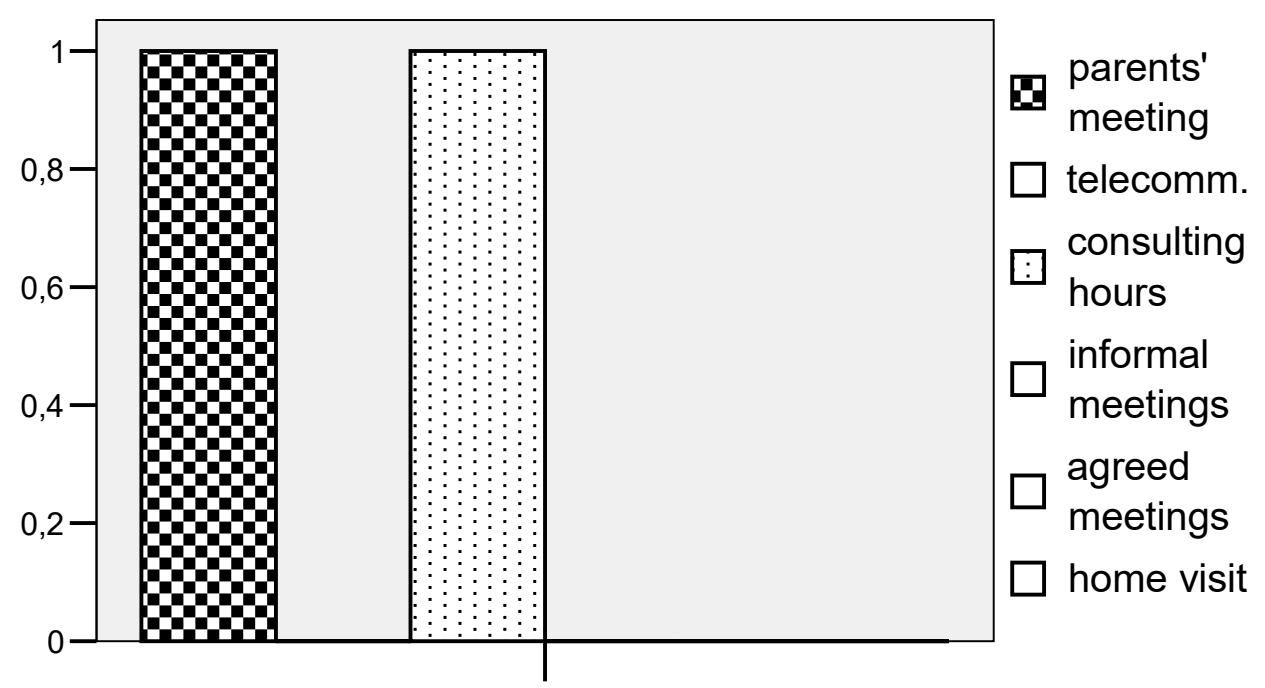

Formal

In Cluster 6, named 'Formal', we can find parents who only use traditional, formal types of contact: they usually go to parents' meetings, and consulting hours, but do not take advantage 
of other flexible forms of keeping contact. They tend to use only those options organized by the school.

Figure 10 - The patterns of contact: Adaptive



Cluster 7, labelled 'Adaptive', combines tradition, personal contact and flexibility. Parents' meetings offer the possibility to inquire about questions regarding the class; during consulting hours parents can talk in private about their child and if they need to they can get information by phone and e-mail in a quick and flexible way. In this cluster the relationship is animated and varied.

These seven clusters were each compared to the other variables which measured the quality of the relationship between parents and teachers. We found that in most cases the order was similar. The results of the Kruskal-Wallis test reached significance $(p=0.000)$ between five variables: the satisfaction with the types of contact, the quality of that contact, the frequency of contact and the satisfaction with the frequency of contact, and the level of cooperation when a problem occurs.

The 'Flexible' and 'Adaptive' forms reached the highest scores on this scale. Moderate scores were achieved by 'Keeping distance', 'Spontaneous' and 'Agreed' patterns of contact in terms of the variables above. The lowest scores were registered with two patterns of contact: 'Formal' and 'Unifacial', so parents are less satisfied with these clusters both in terms of quality and quantity. However, it is indeed thought-provoking that these forms are used by almost half of parents $(47.6 \%)$.

When considering frequency of contact, the order changes: in first place, there are two clusters, 'Flexible' and 'Spontaneous', so the 'Spontaneous' cluster moved up from a moderate score to a higher one. This probably only represents a possibility, i.e., that parents can visit a teacher at any time. However, we could see in the case of the 'Spontaneous' cluster that parents make least use of relationship possibilities in this cluster. The 'Adaptive' cluster lies in the middle range, while the order of the other clusters is the same.

In the case of emotional quality, in first place there are three clusters, 'Spontaneous', 'Adaptive' and 'Flexible'. Each has the same characteristics, i.e. personal and cooperative contact. 
There was no significant correlation in the case of equality, but we can find the same trend, especially regarding the 'Flexible' and 'Adaptive' clusters.

So when parents only go to the parents' meeting or consulting hours, this is the least beneficial of all forms of contact in terms of the relationship. The quality of contact is neither adequate nor frequent enough. These parents are less satisfied with the form and type of contact and they consider problem solving to be the least efficient. This result is very important, because $47.6 \%$ of parents are in this cluster. So more subtle analysis can reveal the dissatisfaction and the lack of contact behind the superficial 'everything is all right' answers given in the case of traditional and formal contact forms.

The parent most satisfied with contact are those who supplement parents' meetings with informal contact or consulting hours and telecommunication, and consequently fall into the 'Flexible' and 'Adaptive' cluster. Traditional settings are needed, but these should be complemented with newer, more flexible, and more private opportunities for contact. The aim of parents' meetings is to inquire about questions concerning the class (ideally in the form of a dialogue), planning and executing collective goals and tasks, answering questions which concern everyone, and problem solving. Personal questions are not relevant here, and special settings need to be created for these. Holding consulting hours in itself is not enough, especially in the strict and formal settings currently typical in schools.

Our first hypothesis was confirmed: frequent and flexible contact possibilities were considered more positive by parents, and this helps to create successful cooperation and to solve any problems that have occurred.

The relationship between children's behavioural symptoms and seven clusters of parentteacher contact and other variables was analysed. The Kruskal-Wallis test $\left(p<0.01^{* *}\right.$ and $\mathrm{p}<0.05^{*}$ ) revealed a significant relationship between the seven clusters of parent-teacher contact and all children's behavioural symptoms. The results are presented in the chart below, where we can see which contact patterns contain the most and the fewest children's behavioural symptoms.

Table 3 - Relationship between the patterns of contact and CBCL scores

\begin{tabular}{|l|l|l|}
\hline Scales of the CBCL & $\begin{array}{l}\text { The highest scores on the } \\
\text { CBCL (the most symptoms } \\
\text { occurring) }\end{array}$ & $\begin{array}{l}\text { The lowest scores on the } \\
\text { CBCL (the fewest } \\
\text { symptoms occurring) }\end{array}$ \\
\hline $\begin{array}{l}\text { Problems with social connection } \\
\text { scale** }\end{array}$ & $\begin{array}{l}\text { Spontaneous } \\
\text { Keeping distance }\end{array}$ & $\begin{array}{l}\text { Adaptive } \\
\text { Flexible }\end{array}$ \\
\hline Anxiety, depression scale* & $\begin{array}{l}\text { Agreed } \\
\text { Spontaneous }\end{array}$ & Adaptive \\
\hline Somatization scale* & Agreed & $\begin{array}{l}\text { Flexible } \\
\text { Adaptive }\end{array}$ \\
\hline Attention deficit scale** & $\begin{array}{l}\text { Agreed } \\
\text { Spontaneous }\end{array}$ & $\begin{array}{l}\text { Flexible } \\
\text { Adaptive }\end{array}$ \\
\hline Deviant behaviour scale** & $\begin{array}{l}\text { Agreed } \\
\text { Keeping distance }\end{array}$ & $\begin{array}{l}\text { Flexible } \\
\text { Adaptive }\end{array}$ \\
\hline Agressivity scale** & $\begin{array}{l}\text { Agreed } \\
\text { Keeping distance }\end{array}$ & $\begin{array}{l}\text { Flexible } \\
\text { Spontaneous }\end{array}$ \\
\hline Internalization* & Agreed & $\begin{array}{l}\text { Adaptive } \\
\text { Flexible }\end{array}$ \\
\hline Externalization $* *$ & Spontaneous & Flexible \\
\hline Total value of problems $* *$ & Agreed & $\begin{array}{l}\text { Adaptive } \\
\text { Flexible }\end{array}$ \\
\hline
\end{tabular}


The children with lowest levels of behavioural problems were those whose parents prefer 'Adaptive' and/or 'Flexible' patterns of contact, as was shown earlier. Consequently, we can affirm that the patterns of contact which were considered positive by parents really are more effective, considering that children have less psychological symptoms where parent-teacher contact works well and can adapt flexibly and efficiently,

Unequivocal tendencies can also be shown for contact patterns which are typical of parents whose children have various behavioural symptoms. The most typical form is 'Agreed'. As I mentioned earlier, in this cluster we can find those parents who are invited in to school by the teacher, or where the teacher makes the appointment or visits the family if there is a problem. It is only when the child has problems with their social relationships (conformity troubles, solitude) that we do not encounter this form of contact, perhaps because it may appear a less acute problem to the teacher. The 'Agreed' form also includes those parents who initiate the appointment, especially when a problem or symptom occurs.

The other form which is typical of parents who experience problems is 'Keeping distance', i.e. when parents usually go to parents' meetings and keep contact with the teacher by telecommunication methods. In this case our investigation does not reveal who initiates the contact, the parent or the teacher (in my experience, in most cases it is the parents who make the first phone call). This group probably includes parents who make do with parents' meetings when there is no problem with the child. When a problem occurs, they get in touch with the teacher. However, personal contact, where they could spend time talking about their child's problem, is not typical. This result is confirmed by teachers' experience that "the parents who really should take part in the parents' meetings are the ones who don't'.

The 'Spontaneous' contact form is also the typical form of parents whose children have several interiorization symptoms. It seems that the child's internal problems - which are less disturbing for the surroundings - do not force the teacher or the parents to make and maintain contact.

Our second hypothesis was confirmed: when parent-teacher forms of contact are more sufficient, children have fewer behavioural problems. Our results agreed with the observations of Füle (2002), Szabó (2003), Hegedüs and Podráczky (2012), and Lannert and Szekszárdi (2015).

Other variables of parent-teacher contact were examined with the Kruskal-Wallis test $\left(\mathrm{p}<0.01^{* *}\right.$ and $\left.\mathrm{p}<0.05^{*}\right)$ which revealed a strong significant relationship between the occurrence of children's symptoms and the quality of parent-teacher contact, the satisfaction with the form and frequency of the contact, the cooperation when a problem occurs and the equality of the contact.

The better the parents considered the quality of contact between themselves and teachers, and the more satisfied they were with its form and frequency, the fewer symptoms were mentioned, and vice versa: the less satisfied they were with the contact, the more symptoms occurred.

This confirms our third hypothesis, that the children of parents who have more positive contact with teachers have fewer behavioural problems. Parents who feel the contact to be a subordinate-superior one reported several symptoms in their children, although these did not include anxiety and interiorization symptoms. There was no significant correlation in the case of the frequency and the emotional quality of the contact. 
KÜLÖNLEGES BÁNÁSMÓD, III. ÉVF. 2017/1.

Table 4. Relationship between the parent-teacher contact and CBCL scores

\begin{tabular}{|l|r|r|r|r|r|}
\hline CBCL scales & $\begin{array}{l}\text { Nature of the } \\
\text { parent-teacher } \\
\text { contact }\end{array}$ & $\begin{array}{l}\text { Satisfaction } \\
\text { with the form } \\
\text { of the contact }\end{array}$ & $\begin{array}{l}\text { Satisfaction } \\
\text { with the } \\
\text { frequency of } \\
\text { the contact }\end{array}$ & $\begin{array}{l}\text { Cooperation } \\
\text { when a } \\
\text { problem } \\
\text { occurs }\end{array}$ & $\begin{array}{l}\text { Equality of } \\
\text { the contact }\end{array}$ \\
\hline $\begin{array}{l}\text { Problems with the } \\
\text { social connection } \\
\text { scale }\end{array}$ & $0.000^{* *}$ & $0.000^{* *}$ & $0.000^{* *}$ & $0.000^{* *}$ & $0.028^{*}$ \\
\hline $\begin{array}{l}\text { Anxiety. } \\
\text { depression scale }\end{array}$ & $0.047^{*}$ & $0.000^{* *}$ & $0.000^{* *}$ & $0.000^{* *}$ & 0.386 \\
\hline $\begin{array}{l}\text { Somatization } \\
\text { scale }\end{array}$ & $0.022^{*}$ & $0.004^{* *}$ & $0.002^{* *}$ & 0.160 & $0.003^{* *}$ \\
\hline $\begin{array}{l}\text { Attention deficit } \\
\text { scale }\end{array}$ & $0.000^{* *}$ & $0.000^{* *}$ & $0.000^{* *}$ & $0.000^{* *}$ & $0.046^{*}$ \\
\hline $\begin{array}{l}\text { Deviant } \\
\text { behaviour scale }\end{array}$ & $0.000^{* *}$ & $0.002^{* *}$ & $0.000^{* *}$ & $0.000^{* *}$ & $0.036^{*}$ \\
\hline Agressivity scale & $0.000^{* *}$ & $0.011^{* *}$ & $0.001^{* *}$ & $0.000^{* *}$ & $0.031^{* *}$ \\
\hline \begin{tabular}{l} 
Internalization \\
\hline Externalization
\end{tabular} & $0.000^{* *}$ & $0.000^{* *}$ & $0.000^{* *}$ & $0.000^{* *}$ & 0.119 \\
\hline $\begin{array}{l}\text { Total value of } \\
\text { problems }\end{array}$ & $0.000^{* *}$ & $0.001^{* *}$ & $0.000^{* *}$ & $0.000^{* *}$ & $0.010^{* *}$ \\
\hline
\end{tabular}

$\mathrm{p}<0.01^{* *} \mathrm{p}<0.05^{*}$

Examining these results from another point of view, we can suppose that parents whose children have fewer symptoms can have better contact with the teacher, since their contact is not hampered with problems, or symptoms that need to be solved, while parents whose children have difficulties considered contact with the teacher much less satisfying.

\section{DISCUSSION}

In view of the results obtained, we can confirm that parent-teacher contact is far from perfect, but it is absolutely necessary to improve it and make it function better. This is even more important, since it seems that the contact between adult authority figures and the way they can cooperate and find solutions when a problem occurs, influences children's mental health and the development of their symptoms. In terms of the practical aspects of school life, we emphasise three main points.

\section{Considering parents' contact patterns during cooperation.}

In our study we found seven patterns of contact. Of these, parent groups who are able to supplement traditional contact forms with more flexible and more private contact possibilities are more satisfied with the form of contact, its frequency, its quality and the level of cooperation when a problem occurs.

This distribution facilitates a more subtle analysis, since the everyday dichotomy (maintain contact / not maintain contact) could change, because there are clearly parents, especially in the younger age group, who are not content with the conventional, rigid forms offered by the school. In schools where there is no other possibility to contact the teacher, parents probably do not maintain any contact, or they are dissatisfied with it. Other possibilities to contact the teacher do exist, however, so if a good, personal relationship were to develop, there is a greater chance they would be more motivated to maintain contact in other ways, too. 
In whatever case, it would be preferable if more parents used personal methods, instead of formal, impersonal, rigid forms of contact. Conventional forms should be reviewed and 'reformed', and alternative forms should be introduced (Szabó, 2006).

The frequency of contact correlates with satisfaction with cooperation, too. This draws attention to the fact that more frequent communication possibilities need to be made available to parents, and it points to the fact that if parents can make positive contact with the teacher, the contact will be more frequent.

Necessarily, the quality of all human relationships depends on both parties; however, in this context the teacher's role, qualifications, and experience are the main factors which can provide a starting point for change and improvement. It is necessary to acquire an approach in which parent-teacher contact is equal and based on cooperation, and to work towards a common goal (the education and welfare of the child).

It is very helpful if a parent has an outstanding ability to build relationships, and has excellent communication and conflict management skills - however, this cannot be an expected requirement. We are, however, justified in expecting that the teacher has these abilities. It is essential that teachers are able to self-monitor and improve their self-awareness in order to recognize the situation adequately and deal with it.

\section{Teacher training}

Here we move on to discuss another aspect which is emphasized by our results. Teacher training (and in-service training) institutions have a significant role in change, since cooperation with parents and review of conventional forms of contact still only have a minor role in teacher training. This problem is not unique to Hungary; there are only a few teacher training programmes in Europe which help prepare teachers to keep in touch with parents (Salamon, 2013).

\section{Experts assisting in the school}

Ideally, teacher developers, speech therapists and school psychologists (most frequently) are present in primary schools to help children who have various symptoms and problems, and their parents. Our results reveal that children's symptoms cannot be treated in isolation. It is necessary to monitor the relationship between the parents and teachers, and to give specialist assistance to improve it (and mediate where necessary).

The increasing use of team-work in schools must be encouraged, and supervision groups must be made a regular feature of school life, so that a child and his/her family do not only contact a teacher when a problem occurs. Teacher-parent groups should be established, in which both parents and teachers can talk, discuss their opinions, and learn the skills required for successful co-operation.

\section{REFERENCES}

F. Lassú, Zs., Podráczky J., Glauber A., Perlusz, A. \& Marton, E. (2012). Nemzetközi kutatások a szülői részvétel hatásáról. In Podráczky J. (szerk.): Szövetségben. Tanulmányok a család és az intézményes nevelés kapcsolatáról. ELTE Eötvös Kiadó: Budapest. 13-42.

Füle, S. (2002). Párbeszéd a szülök és a pedagógusok között. Okker Oktatási, Kiadói és Kereskedelmi Kft: Budapest.

Gádoros, J. (2007). Gyermekviselkedési Kérdőív. Child Behavior Checklist, CBCL, Achenbach, 1991). In: Perczel Forintos, D., Kiss, Zs. \& Ajtay, Gy. (szerk.): Kérdöívek, 
becslöskálák a klinikai pszichológiában. Országos Pszichiátriai és Neurológiai Intézet: Budapest. 130-137.

Hegedűs, J. és Podráczky, J. (2012). Fókuszcsoportos beszélgetések a közoktatási intézmény és a család kapcsolatáról - első reflexiók a kutatás kapcsán. In: Podráczky, J. (szerk.): Szövetségben. Tanulmányok a család és az intézményes nevelés kapcsolatáról. ELTE Eötvös Kiadó: Budapest. 105-124.

Hunyady, Gy. (2002). Iskola-imázs. Iskolakultúra, 12.4. sz. 29-39.

Katona, N. és Szitó, I. (2005). Szerepkonfliktusok felismerése és kezelése a pedagógus-szülö kapcsolatban. Mester és Tanitvány 2.7. sz. 47-59.

Lannert Judit, Szekszárdi Júlia (2015). Miért nem érti egymást szülő és pedagógus? Iskolakultúra, 25.1. sz. 15-34.

Lénárd, S. (2003). Naiv nevelési nézetek. Iskolakultúra, 13.5. sz. 76-82.

Salamon, E.: A szülők bevonása mint az iskolai siker kulcsa. (Download: 2015.06.02.). (Web: http://www.osztalyfonok.hu/cikk.php?id=1246.

Szabó, É. (2006). Szeretettel és szigorral. A iskolai nevelés problémái a szülök és a tanárok szemszögéből. Akadémiai Kiadó: Budapest.

Torgyik, J. (2009). Jó gyakorlatok a multikulturális nevelés köréből. In: Kállai, E. és Kovács, L. (szerk.): Megismerés és elfogadás. Pedagógiai kihívások és roma közösségek a 21. század iskolájában. Nyitott Könyvmühely Kiadó: Budapest. 31-41.

Vámos, Á. (2001). A metafora felhasználása a pedagógiai fogalmak tartalmának vizsgálatában, Magyar pedagógia, 101.1. sz. 85-108.

Winkler, M. (2003). Iskolapélda. Kinek kaloda, kinek fészek. Edge $2000 \mathrm{Kft}$ : Budapest.

2011. évi CXC. törvény a nemzeti köznevelésröl 